\title{
Rolul familiei în formarea unor experți în domeniul STEM
}

\author{
Marinela BĂRNUȚIU (SÂRCA)*
}

Abstract: The role of family in training STEM experts. STEM education involves equal attention to the disciplines of Science, Technology, Engineering and Mathematics. Adding the Arts, respectively Reading, two new concepts called STEAM and STREAM were obtained. The training of STEM experts in today's society is a real necessity in our country. A large share of the trades that will exist in the next 10-20 years have not been invented, and many trades will disappear completely. In addition to the essential role that the teacher has in students training, the teacher-student-parent relationship greatly influences the teaching-learning act. It is well known that the close relationship between school and family leads to improved academic achievement of students, increased motivation and the creation of a positive educational climate. Through this article, I set out to analyze the influence of parenting styles in the training of STEM experts.

Keywords: STEM education, parents, parenting styles, integrated activity, students.

\section{Introducere}

Am păşit cu toții în cea de-a patra eră, cea a digitalizării unde majoritatea locurilor de muncă vor încerca să combine mai multe domenii şi pasiuni. Este foarte important pentru micii școlari să dețină acele abilități care să-i pregătească pentru meseriile viitorului, meseriile STEM.

\footnotetext{
* Drd., Universitatea „Babeș-Bolyai” din Cluj-Napoca.
} 
Marinela

BĂRNUȚIU (SÂRCA)

\section{Educația STEM/STEAM/STREAM}

Educația STEM presupune o abordare integrată a disciplinelor Științe, Tehnologii, Inginerie, Matematică şi este experimentată masiv în SUA. Ulterior au apărut conceptul de educaţie STEAM care include și artele, dar și de STREAM care adaugă Reading-ul. Această abordare dezvoltă elevilor acele abilități necesare integrării active în viața socială. În anul 2019, Forbes enumera cele mai importante zece abilităţi necesare viitorilor angajați, și anume creativitatea, inteligența emoțională, gândirea critică, învățarea activă, luarea deciziilor, comunicarea interpersonală, abilități de conducere, inteligență culturală, abilități tehnologice, capacitatea de schimbare. (Paul, 2018)

Studiile de specialitate relevă faptul că o mare parte dintre aceste abilități pot fi formate elevilor în urma implementării pedagogiei STEM. Cele mai frecvent menționate fiind dezvoltarea gândirii critice a elevilor precum și de fundamentarea STEM Thinking.

În ceea ce privește inteligența emoțională, învățarea activă și luarea deciziilor, trebuie menționat faptul că educaţia STEM sprijină elevii să facă față problemelor din viața reală, îi motivează și le crește încrederea de sine.

În actul de învăţare, alături de profesori, părinții au un rol însemnat, îndeosebi în cadrul învăţământului primar. Pedagogia clasică a adus în atenție în mod repetat relația dintre profesor şi elev, însă tipologia părinților în relație cu școala nu s-a bucurat de o prea mare atenție.

\section{Stiluri parentale}

Cunoașterea mediului familial în care trăiește copilul duce la o mai bună organizare a strategiilor și a modului de realizare a actului de transmitere a cunoștințelor, respectiv formare de priceperi și deprinderi. Informațiile legate de mediul familial pot fi obținute numai printr-o relație pozitivă cu părinții și prin implicarea acestora în viața elevului. 
Cercetările din spaţiul psihologiei educaţiei au clasificat tipologiile parentale în două mari categorii: părinții activi, care se implică activ în procesul de învățare prin care trece copilul și, mai mult decât atât, se consideră responsabili pentru rezultatele copiilor lor, și părinții pasivi, care cred că școala este responsabilă de atenţionarea acestora cu privire la implicarea în viața școlară a copiilor lor, dar și de rezultatele pe care le obțin aceștia.

Diana Baumrind a realizat o cercetare în urma căreia a identificat trei tipuri parentale. Acestea au fost construite în urma utilizării a două dimensiuni importante: suportul parental şi controlul strict. Eșantionul implicat în cercetare a inclus 103 preșcolari din 95 de familii. În urma testelor, interviurilor și studiilor realizate la domiciliu, cercetătoarea a identificat următoarele stiluri parentale: parentajul democratic, parentajul permisiv, parentajul autoritar. În 1983 Eleanor Maccoby şi John Martin au adăugat un al patrulea stil şi anume parentajul neimplicat/neglijent.

În concepția lui Baumrind parentajul autoritar pune accentul pe control şi supunere, căldura sufletească fiind deficitară. Parentajul permisiv pune accent pe exprimare personală și pe autoreglare, controlul fiind scăzut, în timp ce stilul de parentaj democratic combină respectul față de individualitatea copilului cu efortul de a elabora reguli clare și consecvente care trebuie respectate, oferind căldură sufletească copilului.

Părinții neimplicați sunt acei părinți care fug de responsabilitatea de a fi părinte, nu realizează controlul copiilor și nu oferă nici căldură sufletească. Din păcate, consideră respectivii cercetători, este aproape imposibil să transformăm un părinte neglijent, în unul democratic, sau un părinte pasiv într-un părinte activ.

\section{Educația STEM și influența stilurilor parentale}

Relația dintre școală și părinți, în educaţia contemporană, trebuie să fie una strânsă şi să ofere un echilibru între implicarea emoțională și control, aspecte importante pentru educația unui copil. 
Marinela

BĂRNUȚIU (SÂRCA)

Abordarea integrată STEM oferă copiilor posibilitatea realizării inter-conexiunilor între cunoștințe și domenii, stimulează imaginația și creativitatea, crește nivelul angajării și al motivației în actul învățării. Elevii conștietizează importanța disciplinelor și modul în care acestea îi ajută la rezolvarea problemelor din viața reală.

Educația STEM/STEAM/STREAM se realizează prin implicarea tuturor, atât a elevilor, cât și a profesorilor, respectiv a părinților. Învățarea prin intermediul abordării integrate STEM sau STEAM/STREAM face apel la modalităţi de învățare euristice, învățarea prin experimente, observații, predicții care dezvoltă elevilor o serie nouă de abilități.

Strategiile folosite în predarea de tip STEM solicită suplimentar profesorii și de aceea ar fi de dorit să existe un sprijin și din partea părinților. Elaborarea de experimente, observațiile în natură ar fi ideal să se realizeze și acasă împreună cu părințiii. Descoperirea lumii înconjurătoare suscită atenția copiilor de la cele mai fragede vârste, iar familia este primul mediu cu care copilul face cunoștință. În familie, micul școlar poate observa și descoperi lucruri noi, experimentând alături de părinți. Aceste experințe trăite împreună oferă copiilor un nivel ridicat de securitate emoțională și le asigură confortul și independenţa care îi sprijină în activitatea didactică de la școală.

Revenind la stilurile parentale descrise de Baumrind, putem uşor determina faptul că părinții democratici se pliază cel mai bine pe modul de gândire STEM, la pol opus fiind părinţii neimplicaţi.

Părinții democratici și cei activi sunt acei părinți care adesea știu cum să îmbine armonios căldura sufletească cu controlul, oferă copiilor posibilitatea unei comunicări în ambele direcții, iar prin discuții și explicații prezintă clar propriile acțiuni.

Tot acești părinți sprijină activitățile școlare și extrașcolare care oferă elevilor posibilități diverse de dezvoltare, își susţin proprii copii și pe profesorii acestora, comunică eficient cu dascălul de la școală și adesea se implică și ei în realizarea activităţilor STEM în mediul familial. În mediul online, în contextul pandemiei generate de virusul Covid-19, mai mult ca niciodată, părinții creează pagini web, filmulețe și materiale STEM cu aplicabilitate în mediul familial. 
Părinții neimplicaţi vor prefera să se debaraseze pe cât posibil de sarcinile didactice care pot fi derulate în familie, nu vor găsi timpul necesar de a experimenta învățarea prin descoperire alături de proprii copii.

Căldura sufletească scăzută a părinților autoritari, regulile stricte impuse în familie fără explicarea motivelor, dar și cerința de supunere a copilului, în situația în care acesta are comportamente nepotrivite, duc la o distanţare a copiilor faţă de proprii părinți. În lipsa securității emoționale solide și în contextul unor reguli extrem de rigide, experiențele de învățare STEM de acasă se vor realiza anevoie, iar rezultatele nu vor fi cele scontate.

\section{Concluzii}

Abordarea integrată STEM, des întâlnită pe continentul american, deschide elevilor un nou univers, care îi ajută pe aceștia să realizeze inter-conexiuni utile între tehnologii, inginerie, arte, matematică și științe.

Abordările integrate STEM sunt destul de solicitante pentru profesori și părinți, însă implicarea și colaborarea strânsă între familie și școală aduce reale beneficii micilor școlari.

Conform tipologiei stabilite de Baumrind, părinţii democratici, respectiv cei activi, sunt părinții care vor susține implementarea pedagogiei STEM, deoarece vor oferi copiilor sprijinul necesar în descoperirea lumii înconjurătoare prin implicarea în experiențe euristice de învățare.

$\cos 80$

\section{Bibliografie}

1. BABOS, Ioana, CIASCAI, Liliana, „Teachers' Opinions Regarding the Integration of Stem-Based Activities in Primary Education", în International Conference on Education and New Learning Technologies EDULEARN, 2020. Disponibil: https://library.iated. org/publications/EDULEARN20 (accesat la data de 12.09.2020). 
2. BAUMRIND, Diana, „Effects of Authoritative Parental Control on Child Behavior", în Child Development, 37(4), 1966, p. 887-907.

3. Cucoș, Constantin, Pedagogie, ediția a III-a revăzută și adăugită, Iaşi, Edit. Polirom, 2014.

4. Hasni, Abdelkrim, Potvin, Patrice, „Student's Interest in Science and Technology and its Relationships with Teaching Methods, Family Context and Self-Efficacy", în International Journal of Environmental \& Science Education, 10(3), 2015, p. 337-366.

5. KELlEY, Todd, KNOWLES, Geoff, Un cadru conceptual pentru educația STEM integrată, IJ STEM Ed 3, 11, 2016. Disponibil: https://stemeducationjournal.springeropen.com/articles/10.1186/s 40594-016-0046-z (accesat la data de 01.09.2020).

6. LAMBERG, Teruni, TRZYNADLOWSKI, Nicole, „How STEM academy teachers conceptualize and implement STEM education", în Journal of Research in STEM Education, 1(1), 2015, p. 45-58.

7. Li, Yeping, Schoenfeld, Alan, DISESSA, Andrea, GrAESSER, Arthur, BENSON, Lisa, ENGLISH, Lin, DusCHL, Richard, „On Thinking and STEM Education", în Journal for STEM Educ Res, 2/2019, p. 1-13.

8. MACCOBY, Eleanor E., MARTIN, John A., „Socialization in the Context of the Family: Parent-Child Interaction", în Paul H. MUSSEN (ed.), Handbook of Child Psychology. Vol. 4: Socialization, Personality, and Social Development, New York, Wiley, 1983, p. 1-101.

9. MARGOT, Kelly, KeTTLER, Todd, „Teachers' perception of STEM integration and education: A systematic literature review", în International Journal of STEM Education,6(1), 2, 2019. Disponibil: https://stemeducationjournal.springeropen.com/articl es/10.1186/s40594-018-0151-2

10. Melcu, Cornelia, De ce educația STEM?, EDICT - Revista educației”, ISSN 1582 - 909X, 2018. Disponibil: https://edict.ro/de-ce-educatie-stem (accesat la data de 07.09.2020).

11. NICOLA, Ioan, Tratat de pedagogie școlară, Bucureşti, Edit. Aramis, 2003.

12. Papalia, Diane, OldS, Sally Wendkos, Feldman, Ruth Duskin, Dezvoltarea umană, Bucureşti, Edit. Trei, 2010.

13. PAUl, Andreea, Ghidul meseriilor viitorului, 2019. Disponibil: https://inaco.ro/wp-content/uploads/2019/09/Ghidul-meseriilor- 
Rolul familiei în formarea unor experți in domeniul STEM

viitorului_Editia-a-IIa_INACO_30-Sep-2019.pdf (accesat al data de 13.09.2020).

14. PÂINIȘOARĂ, Ovidiu, Ghidul profesorului de succes, Iaşi, Edit. Polirom, 2017.

15. PIAGET, Jean, Şase studii de psihologie, Bucureşti, Edit. Trei, 2017. 